\title{
MODELLING IT BRAND VALUES SUPPLIED BY CONSULTANCY SERVICE COMPANIES: EMPIRICAL EVIDENCE FOR DIFFERENCES
}

\author{
María Ángeles ALCAIDE (D), María Natividad GUADALAJARA (D), \\ Elena DE LA POZA (iD* \\ Center of Economic Engineering, Universitat Politècnica de València, Valencia, Spain
}

Received 23 April 2020; accepted 06 September 2020

\begin{abstract}
Brands are the most precious intangible companies' assets. Company managers need to know their brand value and the aspects determining it. As no transparent brands market exists, the main objective of this study was to model brand values that the world's main valuation consultants publish. The obtained results indicate that $80 \%$ of the value of these brands is accounted for by both the net results of the companies that own brands and their value on the Stock Exchange. These results allow brand values to be estimated using quantitative and objective information by simple methods, unlike those used by valuation consultants. Moreover, one temporal analysis and another for different industries confer these outcomes consistency.
\end{abstract}

Keywords: brand rankings, brand strength, brand value, intangible asset, net results, Stock Exchange, technology sector.

JEL Classification: C51, D22, G30, L96, O16.

\section{Introduction}

The creation and maintenance of brands are becoming more important in today's intensely competitive world. Strong brands can have a leading advantage over weaker brands because consumers are more likely to make a positive evaluation of certain brand and branding aspects based on the information they have access to (Hoeffler \& Keller, 2003). In addition, investing in branding activities creates brand equity. Equity exists when customers are aware of the brand, are loyal to the brand and perceive it as having quality. The awareness, loyalty and quality perceptions are three main components of a successful brand (Seetharaman et al., 2001).

Studies conducted by the brand consulting firm Optimor have shown that brands range between $20 \%$ and $40 \%$ of a company's total value in many sectors (Martín Benito, 2011).

${ }^{\star}$ Corresponding author. E-mail: elpopla@esp.upv.es

Copyright (C) 2020 The Author(s). Published by Vilnius Gediminas Technical University

This is an Open Access article distributed under the terms of the Creative Commons Attribution License (http://creativecommons. $\mathrm{org} / \mathrm{licenses} / \mathrm{by} / 4.0 /$ ), which permits unrestricted use, distribution, and reproduction in any medium, provided the original author and source are credited. 
Thus their valuation is necessary even though they are intangibles. Moreover, being able to isolate and measure this intangible reveals an additional source of value for shareholders that would not exist otherwise.

This evidences the power that brands have acquired in companies, and the importance of making suitable valuations of these assets. Determining this value is also fundamental to know how to create strong brands.

IAS (International Accounting Standard) 38 of International Financial Reporting Standards (IFRS Standards, 2018), IVS (International Valuation Standard) 210 (International Valuation Standards Council, 2017) and VPGA (Valuation Practice Guidance-Application) 6 of the RICS Valuation-Global Standards 2020 (Royal Institution of Chartered Surveyors, 2020) indicate methodologies to value intangibles for accountancy, financing and valuing purposes, respectively. These Standards recognise the three traditional valuing approaches: the costs approach, the income/profits approach and the market approach. They focus only on economic-financial information. Nonetheless as intangibles have no market, this implies some uncertainty for estimating their value. In 2010, the ISO (International Organization for Standardization, 2010) published ISO 10668:2010 on brand valuations. This is the first brand valuation standard to operate worldwide and is a step towards harmonising brand valuation criteria. One novelty lies in ISO 10668 indicating that any valuation should include besides financial aspects, information about customer behaviour (market research and brand strength), as well as legal aspects. Although the ISO standard is free to be fulfilled, the companies that follow the brand valuation requirements that it sets out obtain a higher degree of trust.

Given the importance of brands, some consultancy companies have emerged in recent years that centre on brand valuations and use their own methodologies. They also publish their own brand value rankings that are internationally acknowledged. They all use mixed methods that combine the economic and customer perspectives. In all these methodologies, the consumer perspective is included in brand strength, which attempts to obtain the brand's value as customers perceive it by means of other factors that are not intrinsic to the product itself, like price. The main disadvantage of these methods is that objectivity and transparency are lacking to determine brand strength.

In the present-day, technology-based companies are revolutionising the markets of products, services and finances, which is the greatest exponent of an economy that is undergoing complete transformation. The information technology (IT) sector is characterised by a constantly growing business volume and by contracting personnel (Asikainen \& Mangiarotti, 2016; Cid-López et al., 2015; Yeh \& Chang, 2020). Generally speaking, the business philosophy that their companies adopt influences other sectors in the economy and their business models (Li et al., 2019). This technological revolution not only affects markets, but also the values of the brands of IT sector companies (Ray \& Sharma, 2020). This sector has had more brands in the Top 10 of the most prestigious international brand valuation rankings in the last decade.

The present work empirically evaluates the degree of similarity in international brand valuation rankings that apply to the IT sector. It also estimates the brand valuation models to analyse which percentage of brand values scored by international rankings depends on 
the quantitative, economic-financial and stock exchange information of the companies that own brands in the IT sector. The rest of this value is determined by brand strength or how consumers perceive them, as indicated by the ISO Standard and international consultancy companies, as shown below. If this percentage obtained in our models is high, it implies a major contribution because it will help companies to evaluate their own brands by encouraging transparency and objectiveness.

A temporal study is carried out about brand values to examine the stability of the proposed valuing models with time. It also examines if the models obtained for the set of selected companies from the IT sector coincide with those obtained when the analysis is repeated by classifying the sample into industries according to the product or service offered.

These objectives are shown in detail below:

Objective 1. Study and verify the degree of similarity in the brand valuations in the IT sector reported by international consultancy companies.

The fact that a qualitative component exists in a brand valuation may mean that the valuing methods and valuations reported by consultancy companies differ. To fulfil this objective, it is necessary to empirically demonstrate that these differences exist, and to know the degree of similarity in these consultancy companies' brand valuations. Several theoretical studies (Aaker, 1996; Salinas, 2009; Salinas \& Ambler, 2009) reveal differences between brand valuation methods, but only three empirical studies about the brand values reported by these companies can be found (Alcaide et al., 2019; Bagna et al., 2017; Janoskova \& Krizanova, 2017).

Objective 2. Model the brand value in the IT sector, estimated by international consultancy companies using economic-financial and stock exchange information.

The three main international brand valuation consultancy companies studied herein employ mixed methods to know each brand's value; in other words, they combine quantitative information (basically the company's income or profits) and qualitative information (essentially brand strength). The company's income or profits can be easily obtained from economic-financial information, with which it is possible to estimate models to value brands and to verify their explanatory power. Moreover, their capacity to make future earnings or brand strength can be also measured by the stock exchange information or by the price of the shares of a company that owns the brand because shareholders are willing to pay a higher price for shares if future earnings are expected to improve. This information about shares is accessible in financial markets. The stronger the explanatory power of this quantitative information, the less relevant the qualitative variables will be to value brands and, therefore, the value of brands' subjectivity will lower. Obtaining models that explain the brand's value with only quantitative and objective information will allow brands to be valued without having to resort to more costly marketing methods for this purpose (Bagna et al., 2017; Johansson et al., 2012; Ratnatunga \& Ewing, 2009).

If this second objective shows that brand values depend on a high percentage of quantitative information, our next objective is to analyse if these results remain with time (Obj. 3) and if they do so in all the IT sector industries of our sample (Obj. 4). 
Objective 3. Model the temporal performance of the value of the brands in the IT sector using economic-financial and stock exchange information.

It is interesting to know whether the obtained quantitative models are static or dynamic; that is, if the models are maintained, or not, during the various analysed subperiods, and if any alterations appear that can be explained by the different economic stages over time, which has been previously done in another study (Attig et al., 2013). Attig et al. (2013) divided the study period into equal sized subperiods: firstly into two subperiods and then into four. These authors obtained a different model for each subperiod.

Objective 4. Model the brand valuations in the IT sector by industries.

It is important to know if the above models (Obj. 2) are equally valid for each industry that comprises the IT sector, or if the explicative power of the quantitative variables becomes more or less relevant in each industry.

These objectives are shown in Figure 1 to see their sequencing in more detail, along with the selected sample.

Objective 1, and especially Objective 2, are the main objects of this research. Objectives 3 and 4 are studied to confer the results obtained through Objective 2 consistency and robustness.

This article is arranged as follows: Section 1 offers a theoretical background. Section 2 describes the sample and the employed methodology. Section 3 presents the results. The discussion of the results comes in Section 4. And, finally, the conclusions are shown.

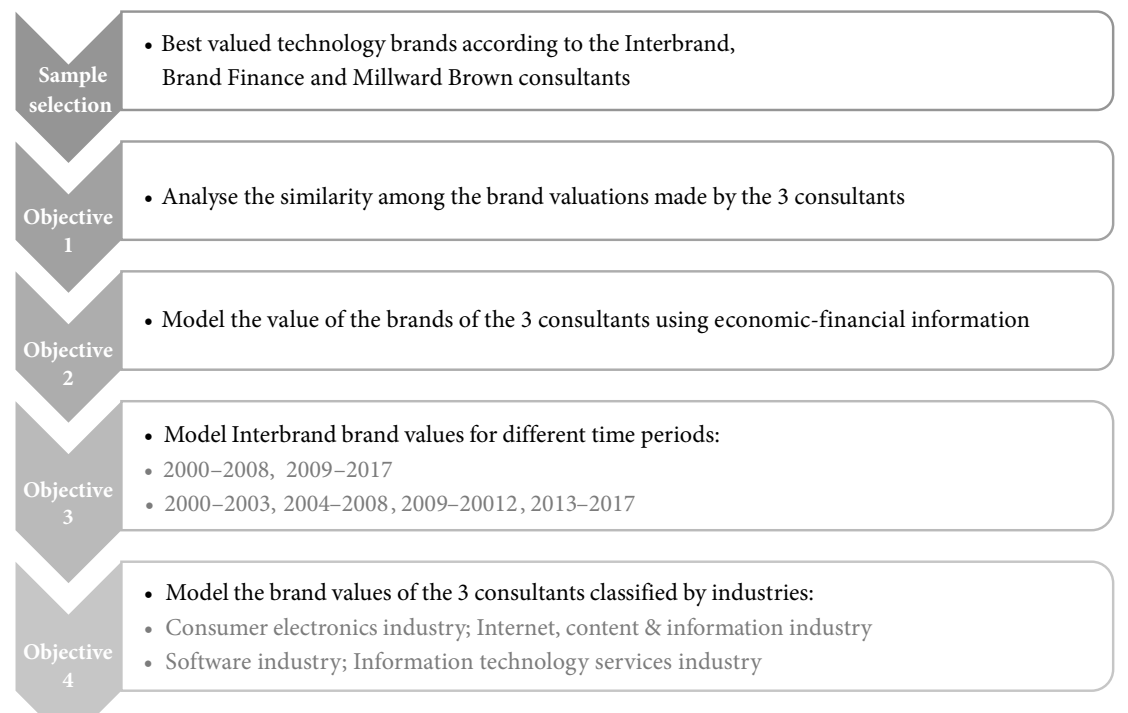

Figure 1. The research model 


\section{Theoretical background}

\subsection{Brands and their valuation}

Defining what a brand is can be difficult. Indeed several definitions can be found in the literature. One of the most frequently used ones is "A brand is a name, term, sign, symbol, or design or a combination of them, intended to identify the goods and services of one seller or group of sellers and to differentiate them from those of the competitor" (Kotler \& Keller, 2006).

Brands are a company's most valuable intangible and, in the past decade, managers in many firms have made development a top priority (Keller \& Lechmann, 2006). To do so, it is essential to understand what affects its reputation, particularly its valuation because a company's value depends on the value that all its assets take. Therefore, the more important companies' intangibles are (Bistrova et al., 2017), the more interest they will show in knowing and specifying their valuation. Nonetheless, the fact that a brand is an intangible means that its valuation is complex and often ambiguous (Janoskova \& Krizanova, 2017).

Nowadays, many brand valuation methods coexist and can be grouped into two main categories depending on the valuation perspective, and are cited in the previous section. In the first category, known as "Marketing perspective" or "Consumer-based methods", methods confer a brand a value according to its trust relationship with consumers (Erdem \& Swait, 1998; Kamakura \& Russell, 1993; Kapferer \& Thoenig, 1991; Keller, 1993; Lambin, 1995) using qualitative variables. In this category, some authors also attempt to measure consumer behaviour and perceptions by associating brand equity with brand strength. Many studies in the literature (Casado et al., 2017; Chao et al., 2009; González et al., 2019; Lee \& Kim, 2019) focus on analysing brand value through brand equity; that is to say, they evaluate how preference is built on a brand, its influence on purchase intention and loyalty to it (Améstica \& King, 2017).

The second category, or the "Economic-financial perspective", uses three traditional valuation approaches (Juliá-Igual et al., 2017; Cheng, 2013) with quantitative variables:

- Market-based: it uses transactions involving brands in similar markets to determine market values compared to other brands (Salinas \& Ambler, 2009). Market methods are based on stock price movements where the goal is to estimate the price of shares (Damodaran, 1996; Simon \& Sullivan, 1993; Virvilaite \& Jucaityté, 2008).

- Cost-based: it accumulates the costs that have actually been or will be incurred by a particular intellectual property product (Abratt \& Bick, 2003). These methodologies are characterised by their difficult calculation.

- Income-based: it focuses on the revenues to be made by the brand in the future, the brand's ability to make profits, or exclusively on its cash flows. This approach consists in discounting future values to the present by applying a discount rate (Srinivasan et al., 2001).

A combination of the three above-cited approaches has been used in some studies (Damodaran, 1994; Haigh, 1996). This approach includes all those models that are not based on a single technique (market, cost, income), but determine the value of a brand by combining two different approaches or more. 
Moreover, and in line with international brand valuation consultancy companies, many studies have combined quantitative and qualitative variables in their methods (Majerova \& Kliestik, 2015; Salinas \& Ambler, 2009) by mixing marketing and economic-financial perspectives.

Although each consultancy company develops its own technique, the main international consultancy companies follow ISO 10668:2010 on brand valuations. This standard specifies a brand valuation framework that includes objectives, valuation bases, valuation approaches, valuation methods, sourcing quality data and assumptions. It also specifies methods to report the results of such valuations (International Organization for Standardization, 2010).

\subsection{The most well-known international consultancy companies}

The best-known consultancy companies are the British Interbrand and Brand Finance, and the American Millward Brown. All three estimate the brand's value according to the income attributed to the brand and the brand strength estimated with marketing methods, and defined as the capacity to make future earnings. The methodology employed by all three is detailed in Section 2.2.1.

Consultancy companies Interbrand and Millward Brown have annually published their ranking with the Top 100 best brands worldwide since 2000 and 2006, respectively. Brand Finance has published its Top 500 ranking since 2007. These rankings are used by authors (Basgoze et al., 2016; De Oliveira et al., 2018; Flisikowski \& Kucharska, 2018; Kucharska et al., 2018; Kim, 2019; Zahari et al., 2020) as a basis to build their models, but the Interbrand ranking is that most widely used by researchers (Agus \& Salas, 2017; Johansson et al., 2012; Ratnatunga \& Ewing, 2009).

Basgoze et al. (2016) analysed the effects of brand value announcements on stock returns of Turkish firms during the 2010-2014 period by the event study methodology, and using Brand Finance Turkey's 100 ranking list as a data source. They concluded that companies earned abnormal positive returns 7 months after announcements. Kucharska et al. (2018) employed the Most Valuable Global Brands 2011-2015 rankings powered by Brand Finance to reveal that global brands contribute to national economies measured by gross domestic product (GDP). In the same year, Flisikowski and Kucharska (2018) extended this study by confirming the relation between brand value and GDP per capita. They also observed that spatial dependencies matter for brand values with the spatial cross-regressive model (SCM). In 2019, Zahari et al. (2020) investigated the effects of CSR practices on financial-based brand equity in the Malaysia Top 100 brands by calculating brand value by adopting the same formula as Brand Finance. They found that CSR practices, such as environmental, community, workplace and marketplace, involved and enhanced their brand equity. De Oliveira et al. (2018) used the Millward Brown ranking to compare the performance of stocks of companies with high brand equity with the stocks of other companies listed on the Stock Market of emerging Latin America countries. They concluded that the valuable brands portfolio presents the lowest investment risk in these emerging markets. More recently, Kim (2019) used this same ranking to examine the linguistic characteristics, which are found in the Chinese translation of 100 major multinational brands. 
Ratnatunga and Ewing (2009) extended Interbrand's brand strength valuation model by developing an ex ante approach to guide managers in their budgeting and strategic decision-making processes geared towards building brand value. It empirically tested the model in an Australian telephone company with an internationally recognised brand. Johansson et al. (2012) also used the Interbrand ranking to investigate how some of the strongest brands in the US market fared in financial performance terms during the Fall 2008 Stock market downturn. Agus and Salas (2017) evidenced how corporate social responsibility (CSR) strengths positively affect the brand value level from the Interbrand listing, and how CSR concerns adversely affect changes in brand value and brand ranking. Alcaide et al. (2020) supported the relation between brand value and the CSR of IT companies. These authors used valuations of the three consultants, and concluded that Brand Finance considers CSR in brand value more than the other two consultants.

Other than this last work, only two others (Bagna et al., 2017; Janoskova \& Krizanova, 2017) have jointly studied the brand valuation rankings of these three international consultancies. The first research work analysed a sample of 71 brands from listed companies for the 2013-2015 period and concluded that the Brand Finance method is the most prudent brand evaluation one. It also developed models to explain companies' market capitalisation based on the three consultants' brand values and companies' income by obtaining adjusted $\mathrm{R}^{2}$ values of around $90 \%$ for all three consultants. They explained brand value based on revenue, sales and sales growth with lower $\mathrm{R}^{2}$ values (between $58 \%$ and $73 \%$ ) for Brand Finance and Interbrand, respectively.

In contrast, Janoskova and Krizanova (2017) made a pairwise comparison on 12 global well-known brands from different sectors for the 2013-2016 period and calculated Pearson's and Spearman's correlation coefficients. They found statistically significant differences among rankings. No regression model was developed in their, and only previous statistics were obtained.

Both studies share one aspect: they globally analysed brands from different sectors without drawing individual conclusions for each sector. In addition, they only analysed a few years ( 3 and 4, respectively), and both agreed that the Brand Finance method was more prudent than the others.

The consulted literature confirms the existence of many studies on brand values in different fields: customer satisfaction, relation with GDP (Ökten et al., 2019; Asfuroglu et al., 2020) and CSR, etc. Moreover, the vast majority of studies merely used the value provided by only one consultant. However, only three works analysed the brand value of the three valuation consultants together, two of which modelled brand value, one was based on the CSR (Alcaide et al., 2019), and another on income, sales and sales growth (Bagna et al., 2017).

\subsection{Brand value and firm's finance performance}

Today affirming that the brand value of a strong brand would positively affect a company's performance (Aaker, 1996; Yang et al., 2019) would seem obvious as these brands have the potential to create competitive advantages in companies. On the contrary, a weakened brand with a bad reputation would have a negative effect. This idea was verified by Pahud de Mortanges and Van Riel (2003), who examined the effect of brand value on the firm's value for a 
number of Dutch companies during the 1993-1997 period. Their findings demonstrated that brand value significantly affects the firm's value (total shareholder return, earnings per share, market-to-book ratio). More recently, Honarmandi et al. (2019) also confimed the positive impact of brand value on company profits but, in this case, in two significant industries operating on the Tehran Stock Exchange: petrochemical and banking industries, which stand for B2B (business to business) and B2C (business to consumer) businesses, respectively. These authors used monthly data from June 2008 to June 2018. These results also confirmed that the effect of brand value on profitability in B2C businesses (banking industry) is significantly stronger, almost double, than for the $\mathrm{B} 2 \mathrm{~B}$ (petrochemical industries) business group. Another more recent study (Dorfleitner et al., 2019) confirmed that the most valuable brand portfolio generates the shareholder value. This study also found that the outperformance of the most valuable brand is much greater during market turmoil than during normal periods, and that outperformance is driven by only a few industries (business services, technology, sporting goods, retail). Therefore, investing in the full sample of valuable brands, rather than in specific industries, is apparently more prudent. In the same year, He et al. (2019) linked brand equity and firm-level productivity by providing new ideas. They analysed and found that R\&D and human capital improved the brand value of Chinese listed companies, especially in large, state-owned and manufacturing companies.

All this information verifies that the literature corroborates the positive impact of brand value on a company's value, especially when it is measured as a shareholder's performance (Eng \& Keh, 2007; Matsumura et al., 2019; Bank et al., 2020). Furthermore, the study of Dutordoir et al. (2015) attempted to learn more about the variables that moderate brand value, e.g., a firm's value relation, and they reported evidence for significant stock price reactions to the Interbrand brand value changes.

We observed that all the studies that related brand value to a firm's performance had very different purposes to that herein proposed and, as mentioned earlier, none used the brand value of the three international consultants together. So we consider that we are bridging a gap in the literature.

\section{Method}

\subsection{Sample selection}

The brand value information employed in the present study is provided by brand rankings, and our sample was selected based on these rankings. The criterion adopted to select the sample was that companies had to come from the IT sector, in accordance with the valuation consultants' classification, and they had to be found in these rankings in some year during the 2000-2017 period and in the top 100 in at least two of the three studied world brand valuation rankings. Consequently, the companies forming the sample are: Accenture, Adobe, Amazon, Apple, Baidu, Cisco, Facebook, Google, HP, IBM, Intel, Microsoft, Netflix, Oracle, Samsung, Salesforce, SAP and Sony. Nonetheless, some brands did not meet the criterion set in some years. For example, Sony was only present in one ranking in 2017, and it also happened with Facebook in 2010 and 2011, Salesforce and Netflix in 2016, and Baidu between 2009 and 2017, except for 2016. 
All previous brands were classified in the IT sector by the three consultants. However, these three consultants do not coincide with the sectorial classification of some brands. Thus, Amazon is classified in the IT sector according to Brand Finance, but in the Retail sector according to Interbrand and Millward Brown. Despite this, we added Amazon to the sample because of the importance attached to its brand value, and also because other important sources, such as the New York Stock Exchange or Nasdaq, have placed it in the IT sector. Therefore, the sample comprises 18 brands. Obviously there are plenty more technology-based companies in the world, but they do not all appear in these valuation consultants' Top 100. Hence their brand values are unknown, which is essential information to obtain valuation models.

Table 1 presents these companies grouped in the industry they belong to according to the Global Industry Classification Standard (GICS), along with some basic economic-financial data to show the sample's profile.

The 18 companies forming the sample are on the Stock Exchange. Four belong to the consumer electronics industry, five to the software industry, five to the Internet content \& information industry, two more to the information technology services industry, one to the communication equipment industry and one to the semiconductors industry.

To conduct this research, information was collected from secondary sources. Firstly, brand valuations (millions \$) were provided by Interbrand, Millward Brown and Brand Finance, as mentioned at the start of this section. This information was collected from the websites of these three international consultancy companies. The total number of brand value data came to 553; 243 corresponded to Interbrand (period 2000-2017), 131 to Brand Finance (period 2007-2017) and 179 to Millward Brown (period 2006-2017).

Secondly, economic-financial information was used and was taken from the annual accounts of the companies owning the selected brands. This information covers the 2000-2017 period. The mean Stock Exchange listing value was obtained monthly from the Yahoo Finance website. Next the mean listing value was calculated every year from the mean of the values adjusted at the end of each month. All the companies' listings were in American dollars, except for Samsung, whose listing value was converted from South Korean won (KRW) into USD \$.

The economic and stock exchange variables (17) taken into account to express the companies' economic-financial information were: accounts receivables, current assets, current liabilities, dividends, dividend per share, financial expenses, net assets, net results, number of employees, number of shares, operating income, research and development (R\&D), sales, tax rate, total assets, total liabilities, stock exchange listing.

This information was used to calculate a set of 14 other variables: earnings per shares (EPS $=$ Net result $/$ No. Shares), price to earning (PER = Listing value / EPS), profitability from dividends (dividend per share / listing value $\times 100$ ), financial profitability (Return on Equity or ROE $=$ Net result / Total stakeholders'equity $\times 100$ ), economic profitability (Return on Assets or ROA $=$ Operating income $/$ Total assets $\times 100$ ), accounting value (Net assets / No. shares), accounting / listing value, book value (accounting value / listing value), liquidity (Current assets / Current liabilities), debt (Total liabilities / Total liabilities + Net assets), leverage (Total liabilities / Total assets $\times 100$ ), payout (Dividends / Net result), sales per employee (Sales / No. employees), and margin (Sales / Operation income). 


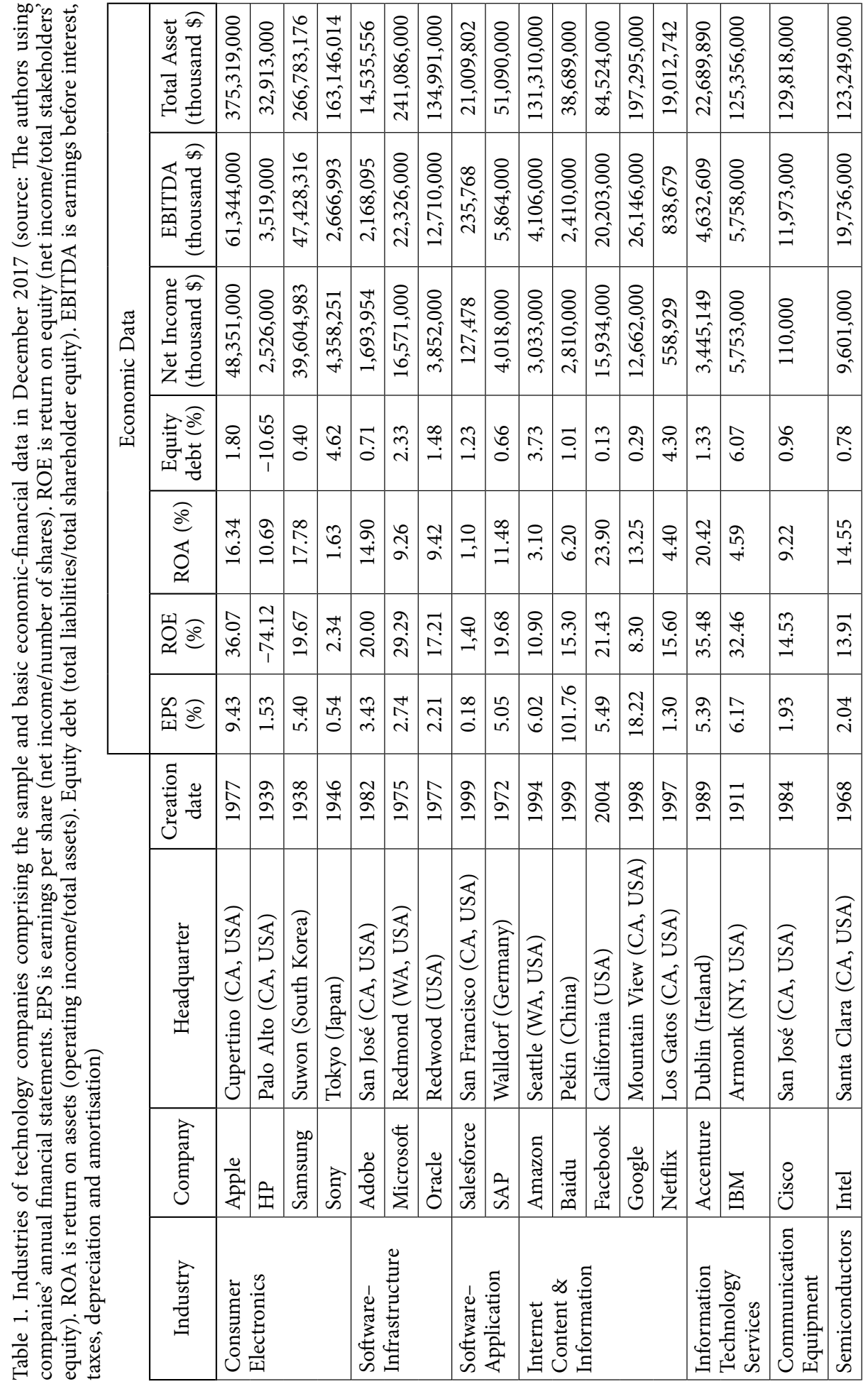


Finally, the time variable was added as a control variable, where $t=1$ corresponded to the first analysed year, $t=2$ to the second year, and so forth. Thus the economic variables and the control variable that formed part of this study came to 32 . With all this information, a database with 553 rows of brand values and 37 columns was created ( 32 previous variables, brand value and three dummies corresponding to each ranking).

\subsection{Methodology}

\subsubsection{Methodology employed by consultants}

The brand valuation methodology developed by the three consultants herein referred to is provided below in detail:

Interbrand: it was founded in 1974, and was the first company to receive ISO 10688 certification. The mathematical expression is as follows:

$$
\text { Brand Value }=\sum_{i=1}^{5} \frac{G_{i}}{(1+r)^{i}}=\frac{G_{1}}{(1+r)^{1}}+\frac{G_{2}}{(1+r)^{2}}+\ldots+\frac{G_{5}+V_{5}}{(1+r)^{5}},
$$

where: $G_{i}$ - earnings from the brand. It is obtained by multiplying the operative net profit after the company's taxes by a percentage of earnings attributed to the brand. This percentage is obtained by means of quantitative-qualitative research, after revising the historic income obtained by brands in the industry, or using a panel of experts in valuing the brands of Interbrand. These financial outcomes are analysed for a set 5-year period; $r$ - the brand risk rate. This rate is unique for each brand and is calculated using an algorithm that the consultancy company has developed. This algorithm is based on brand strength and is measured by 10 indicators: four belong to the internal dimension (clarity, governance, commitment and responsiveness) and six to the external dimension (authenticity, relevance, differentiation, consistency, presence, engagement). Interbrand values the set of these indicators over 100, and in such a way that the higher the score, the better BS is (Interbrand, 2019); $V_{5}$ - the residual brand value in year 5 or a terminal value.

Brand Finance: it was founded in 1996. The mathematical expression is as follows:

$$
\text { Brand Value }=\sum_{i=1}^{n} \frac{I_{i}}{(1+r)^{i}}=\frac{I_{1}}{(1+r)^{1}}+\frac{I_{2}}{(1+r)^{2}}+\ldots+\frac{I_{n}+V_{n}}{(1+r)^{n}},
$$

where: $I_{i}$ - the brand's specific income. It calculates this income by multiplying the company's income by the percentage attributed to the brand, and it estimates these expected incomes based on historic incomes, equity analysis forecasts and economic growth rates; $r$ - the royalty rate. It is defined as a function of the brand strength Index and the sector's royalty rate range. The brand strength Index is calculated on a scale from 0 to 100 based on several relevant attributes of an integral balanced scorecard. The royalty rate range for each sector is calculated by comparing agreements about the licences of other comparable brands in different databases (The Brand Finance Group, 2019); $V_{n}$ - the residual brand value in year $\mathrm{n}$ or the terminal value. 
Millward Brown: was founded in 1973, but it was not until 1987 before it became a world company. It forms part of the Kantar Group, the world's second biggest market research company. The mathematical expression is as follows:

$$
\text { Brand Value }=\mathrm{G} \cdot \mathrm{BM} \cdot \% \text { Brand Contribution, }
$$

where: $\mathrm{G}$ - the brand's earnings. This is obtained by multiplying the company's earnings by the percentage of income corresponding to the brand. This percentage is estimated by analysing the company's financial data as well as information from other sources like Kantar Retail; BM - Brand Multiple. This is used to calculate future earnings as a multiple of current earnings $(\mathrm{G})$. This multiple is estimated using the information supplied by Bloomberg; $\%$ Brand Contribution - it obtains brand value in consumers' minds. To do so, it focuses on the three aspects of brands that make people buy more and pay more for certain things: being meaningful, being different, and being salient (by coming to mind quickly and easily). To determine purchases volume and the extra price that consumers are willing to pay for the brand, quantitative consumer research is conducted both online and face-to-face worldwide (Kantar, 2019).

Brand strength is obtained in the BM and \% Brand Contribution values.

The only quantifiable and objective part of mathematical expressions (1), (2) and (3) is the company's profit. Conversely, the percentage of profit attributed to the brand and its brand strength are estimated by each ranking differently, which can provide distinct brand values. This is the main drawback of these methods.

\subsubsection{Methodology used in the analysis}

The methodology used in this work to study the degree of similarity in the brand values of the technology companies with the most valued brands over time (Obj. 1) was a descriptive statistic analysis: mean, standard deviation and coefficient of variation ( $\mathrm{CV}=$ mean scores / standard deviation) (Alcaide et al., 2019). It would be interesting to obtain high values because this would indicate more similarity among the assessments made by all three consultants.

The methodology followed to analyse Obj. 2 was a multivariate linear regression analysis by Ordinary Least Squared (OLS) (Rodríguez et al., 2011; Wang et al., 2012). The equation of the model was:

$$
Y=\alpha+\beta_{1} X_{1}+\ldots+\beta_{m} X_{m}+\beta_{t} T+\varepsilon,
$$

where: $Y$ - each company's score provided by Interbrand, Millward Brown and Brand Finance every year; $\alpha$-Constant term; $\beta_{1} \ldots \beta_{m}, \beta_{t}$-Coefficients of the explanatory variables (economic-financial and time); $X_{1} \ldots X_{m}$ - Explanatory economic-financial variables; $T$ Time variable; $\varepsilon$ - Random disturbance term.

We ought to bear in mind that in order to obtain brand values, the valuation consultants' methodologies always include companies' results, as well as another representative component, that of the brand being accepted by the market. The brand models created in this paper select two objective and quantitative variables that include these two aspects. A model was firstly obtained for each consultancy company by taking the company's net result as the only explanatory variable to be able to understand and compare which part of each company's 
brand value could be explained only by this quantitative information, from which the three consultancy companies began with in their methodologies. This gave three models. Secondly, the share listing was added and it acted as an indicator of the company's future profit expectations. With these two variables, two models were obtained for each valuation consultant (Models 1 and 2).

Next in order to consider the influence of the 32 economic-financial/stock exchange variables on each consultant's brand value, they were all included in the model. However, in order to reduce the number of variables and to eliminate any possible multicollinearity, a factor analysis was carried out by Principal Components Analysis (PCA) using Varimax rotation (version 20 of the SPSS software). In this way, a third model was obtained by considering the components obtained as explanatory variables. Finally, a fourth model was created which took a variable of each principal component and the time control variable as explanatory variables. This Model 4 offers an advantage over Model 3 because the explanatory variables are perfectly defined and interpretable.

To reinforce Obj. 1, three models were obtained for all the companies as a whole where, apart from the previous independent variables, three dummy variables related to each consultancy company were added (with 1 if the ranking scored a company, and 0 otherwise).

In order to verify and to make our results more consistent, two more analyses were done by replicating the methodology employed by OLS, firstly for the different time subperiods (Obj. 3), and finally by classifying the sample into industries (Obj. 4). In these last two objectives, only the variables used in Model 4 of Objective 2 were employed.

The models' goodness of fit was measured by the adjusted $\mathrm{R}^{2}$ and Student's $\mathrm{t}$. The considered error levels were $0.5 \%, 1 \%$ and $5 \%$. Multicollinearity was measured by the condition index (CI) and the variance inflation factor (VIF).

\section{Results}

Objective 1. Study and verify the degree of similarity in the brand valuations in the IT sector reported by international consultancy companies.

Table 2 offers the results obtained by the descriptive statistics. The first column shows the year and the three columns following the values corresponding to each consultancy company. For each ranking, the mean value of the brands was taken. The number of analysed brands $(n)$ and their standard deviation $(\sigma)$ are shown in brackets. The total number of brands studied in each ranking, and their mean, minimum, maximum values and range, are found at the bottom of Table 2 .

For the three companies, the mean and standard deviation values underwent a generalised increase with time, particularly Millward Brown, except for the first years for Interbrand.

Of the results shown at the bottom of Table 2, we see that the mean brand value obtained by Interbrand is 29,755 millions \$, 33,258 millions \$ for Brand Finance and 46,046 millions $\$$ for Millward Brown. Whereas the first two agencies gave a similar mean value, Millward Brown gave higher values than the other two. The highest value given by this agency during the study period was 246,992 millions \$ (Apple in 2015), while the maximum value given by Interbrand was 184,154 millions \$ (Apple in 2017) and the highest by Brand Finance was 
Table 2. The mean brand value of each consultancy company for the high-value brands of the IT sector per year (nominal values in millions \$), number of analysed companies $(n)$, standard deviation $(\sigma)$ and other descriptive statistics results

\begin{tabular}{|c|c|c|c|}
\hline Year & Interbrand & Brand Finance & Millward Brown \\
\hline 2017 & $46,683(17 ; 49,699)$ & $54,007(12 ; 37,451)$ & $68,477(18 ; 78,208)$ \\
\hline 2016 & $48,364(15 ; 48249)$ & $45,830(13 ; 39,600)$ & $60,553(18 ; 71,342)$ \\
\hline 2015 & $45,850(15 ; 45291)$ & $46,907(12 ; 35,635)$ & $61,121(19 ; 67,404)$ \\
\hline 2014 & $40,300(15 ; 35118)$ & $40,093(13 ; 30,110)$ & $52,593(15 ; 50,096)$ \\
\hline 2013 & $37,107(15 ; 31168)$ & $33,927(12 ; 23,811)$ & $47,485(15 ; 51,303)$ \\
\hline 2012 & $32,631(15 ; 25563)$ & $30,398(12 ; 18,342)$ & $47,573(15 ; 50,697)$ \\
\hline 2011 & $28,346(14 ; 20385)$ & $25,217(12 ; 11,669)$ & $45,042(15 ; 44,418)$ \\
\hline 2010 & $25,119(14 ; 19114)$ & $21,502(11 ; 9,489)$ & $36,961(15 ; 35,140)$ \\
\hline 2009 & $22,502(14 ; 17377)$ & $17,967(11 ; 9,035)$ & $34,177(14 ; 29,549)$ \\
\hline 2008 & $23,472(13 ; 17258)$ & $23,213(12 ; 13,563)$ & $33,410(13 ; 25,012)$ \\
\hline 2007 & $21,745(13 ; 17369)$ & $20,091(11 ; 10,649)$ & $25,611(12 ; 18,045)$ \\
\hline 2006 & $20,439(13 ; 17494)$ & & $22,386(12 ; 15,999)$ \\
\hline 2005 & $19,754(13 ; 18250)$ & & \\
\hline 2004 & $20,579(12 ; 19072)$ & & 246,992 \\
\hline 2003 & $20,078(12 ; 19654)$ & & \\
\hline 2002 & $19,442(12 ; 19528)$ & & 179,046 \\
\hline 2001 & $21,466(11 ; 20644)$ & & \\
\hline 2000 & $24,195(10 ; 22731)$ & & \\
\hline N & 243 & $14,49,918$ & \\
\hline Mean & 29,755 & 33,258 & \\
\hline Range & 181,024 & & \\
\hline Minimum & 3,130 & & \\
\hline Maximum & 184,154 & & \\
\hline
\end{tabular}

145,918 millions \$ (Apple in 2016). Thus coincidences can be found in the highest valued brand in one same company, but in different years. Conversely, the lowest valued brand was given by Interbrand with 3,130 millions \$ (Amazon in 2001), 5,494 millions \$ by Brand Finance (Amazon in 2007), and 5,524 millions \$ by Millward Brown (Facebook in 2010). In this case, no coincidences appeared in either the same company or the same year. Apart from Millward Brown being the consultancy company to provide the highest values, it also presented the widest variability; that is, the distance or difference between its maximum and minimum points was longer or bigger, respectively (range $=241,468$ millions $\$$ ). So we can state that Brand Finance was the agency that offered the stable valuations (narrower range).

To evaluate the similarity among the valuations provided by the three brand rankings on a yearly basis, the CV was calculated for the 2007-2017 period. Table 3 indicates that the CVs ranged from 0.98 (Facebook in 2012) to 70.56 (Sony in 2016). The "Mean CV" column shows that Facebook, Google and SAP obtained the most diverse valuations from all three consultancy companies (also Netflix and Salesforce, although these brands only appeared in 
the last year). Conversely, Sony was the brand whose valuations showed the most coincidences. We can also see that years 2010, 2011 and 2017 were those with the biggest differences (with 2.63, 2.90 and 2.96), while 2007, 2015 and 2016 (with 6.27, 6.07 and 7.11) obtained very similar valuations.

Objective 2. Model the brand value in the IT sector, estimated by international consultancy companies using economic-financial and stock exchange information.

The large number of economic-financial information led us to perform a PCA. Its results indicated a Kaiser-Meyer-Olkin value of 0.731 , which reveals that the analysis was adequate. Three components were obtained to be used in Model 3 (Appendix).

Table 4 shows the linear regression models obtained for each consultancy company according to Eq. (4). Four models were obtained for the consultancy firms as a whole and for the firms Interbrand and Millward Brown. Thus, in the first model the company's Net results was the only explanatory variable; the second was adding the Listing value; the third included the three components resulting from the PCA; the fourth included the explanatory variables, namely Listing value, Dividend per share and Net result, as the representative variables of each component, respectively, as well as the Time control variable. Only the first three models were obtained for Brand Finance.

Table 3. The CVs of the brand rankings' scores for each brand and year for the high-value brands of the IT sector

\begin{tabular}{|l|c|c|c|c|c|c|c|c|c|c|c|c|}
\cline { 2 - 12 } \multicolumn{1}{c|}{} & 2007 & 2008 & 2009 & 2010 & 2011 & 2012 & 2013 & 2014 & 2015 & 2016 & 2017 & Mean CV \\
\hline Accenture & 3.89 & 2.52 & 2.19 & 2.17 & 2.23 & 2.38 & 2.61 & 2.41 & 2.63 & 2.62 & 2.51 & 2.56 \\
\hline Adobe & & & & & & & & & 8.45 & 4.45 & 5.65 & 6.18 \\
\hline Amazon & 18.85 & 3.58 & 1.55 & 1.79 & 1.72 & 3.45 & 3.18 & 2.65 & 4.11 & 2.93 & 2.77 & 4.23 \\
\hline Apple & 2.17 & 1.37 & 1.10 & 1.14 & 1.03 & 1.74 & 2.31 & 5.62 & 3.02 & 4.43 & 2.73 & 2.42 \\
\hline Baidu & & & & & & & & & & 2.54 & & 2.54 \\
\hline Cisco & 14.43 & 7.07 & 2.98 & 2.91 & 2.56 & 2.18 & 2.07 & 2.52 & 2.63 & 2.54 & 2.94 & 4.08 \\
\hline Facebook & & & & & & 0.98 & 1.52 & 1.44 & 1.41 & 1.41 & 1.83 & 1.43 \\
\hline Google & 1.38 & 1.66 & 1.34 & 1.50 & 1.95 & 2.46 & 2.76 & 2.47 & 2.54 & 2.09 & 2.33 & 2.04 \\
\hline HP & 6.99 & 5.46 & 15.47 & 4.31 & 6.60 & 10.41 & 3.50 & 8.83 & 7.44 & 2.91 & 3.72 & 6.88 \\
\hline IBM & 3.09 & 4.51 & 2.82 & 2.33 & 2.13 & 2.00 & 2.04 & 2.23 & 2.21 & 2.07 & 1.74 & 2.47 \\
\hline Intel & 4.07 & 5.64 & 2.70 & 2.17 & 2.04 & 2.08 & 2.00 & 2.04 & 3.06 & 2.72 & 2.57 & 2.83 \\
\hline Microsoft & 4.35 & 4.40 & 2.40 & 2.63 & 3.39 & 3.87 & 4.78 & 4.38 & 3.00 & 2.91 & 2.65 & 3.52 \\
\hline Netflix & & & & & & & & & & & 1.93 & 1.93 \\
\hline Oracle & 2.73 & 2.26 & 2.87 & 2.72 & 3.02 & 6.71 & 4.99 & 7.48 & 8.12 & 6.37 & 7.86 & 5.01 \\
\hline Salesforce & & & & & & & & & & & 1.76 & 1.76 \\
\hline Samsung & 6.72 & 4.92 & 2.20 & 3.65 & 3.16 & 2.25 & 2.14 & 1.87 & 1.64 & 1.62 & 2.52 & 2.97 \\
\hline SAP & 2.82 & 2.00 & 2.19 & 2.27 & 2.49 & 2.00 & 1.66 & 1.82 & 2.07 & 1.54 & 1.77 & 2.06 \\
\hline Sony & 10.01 & 2.66 & 3.11 & 4.62 & 5.36 & 4.86 & 9.34 & 3.67 & 38.66 & 70.56 & & 15.29 \\
\hline Mean CV & 6.27 & 3.70 & 3.30 & 2.63 & 2.90 & 3.38 & 3.21 & 3.53 & 6.07 & 7.11 & 2.96 & \\
\hline
\end{tabular}




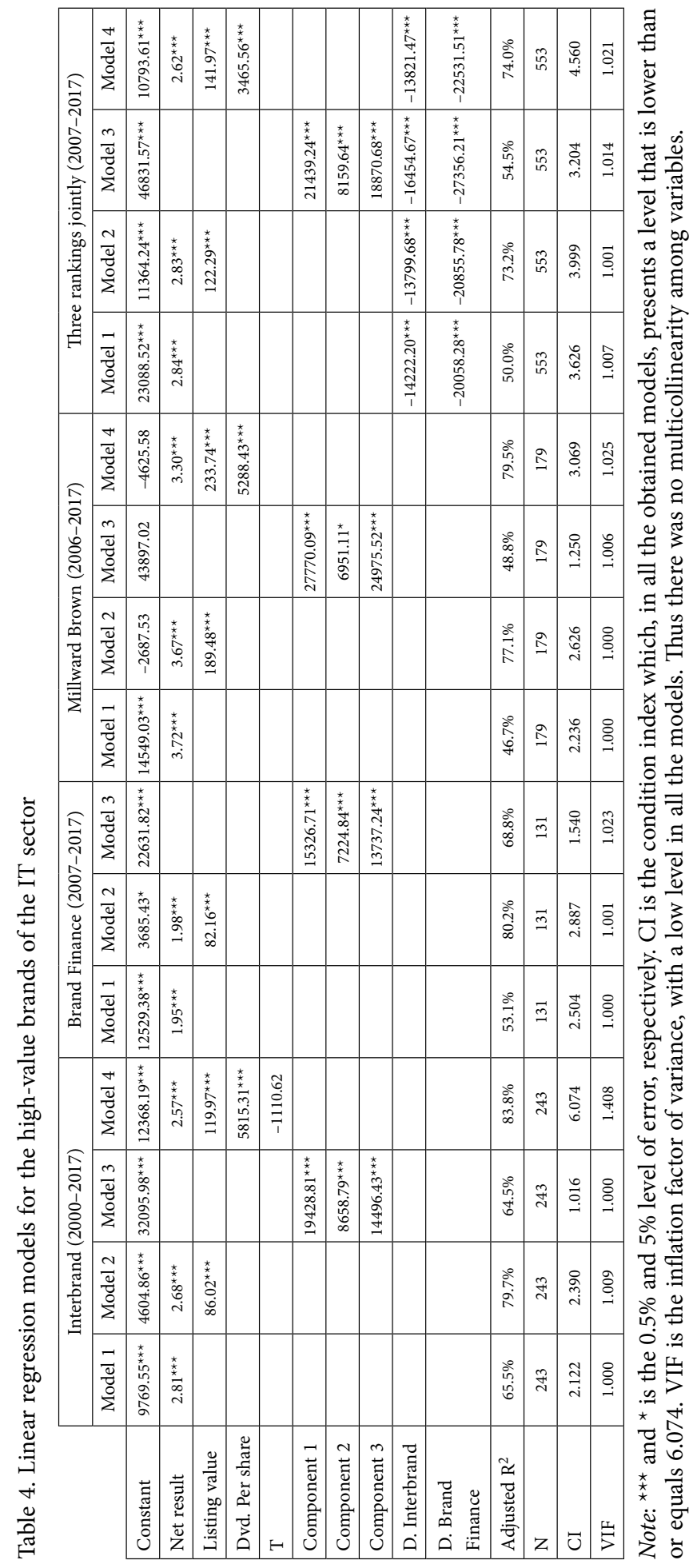


The overall models for all three consultancy companies were obtained for the years for which data were available for all three companies (2007-17) using the reference company, namely Millward Brown.

The residuals were analysed and it was verified that no multicollinearity existed among the variables for any model. The CI and VIF obtained lower values, which went below the threshold of 30 and 7, respectively (Gujarati, 2003).

In the models that depended only on the variable Net result (Models 1), this variable was capable of explaining between 46.7\% (Millward Brown) and 65.5\% (Interbrand) of the brand value given by the consultancy companies, while the joint model explained $50.0 \%$. This means that the Net result of a company owning a brand defined $46-65 \%$ of the brand value from brand rankings, while the rest was accounted for by the brand's qualitative aspects.

When the shares listing was added (Models 2), explicatory power rose to $80.2 \%$ (Band Finance) and 79.7-77.1\% (Interbrand and Millward Brown) of the brand value given by the consultancy companies, while the joint model rose to $73.2 \%$, which is a mean increase of $20-30 \%$.

In the models generated with the three components (Models 3), the explanatory power ranged between $48.8 \%$ and $68.8 \%$ for Millward Brown and Brand Finance, respectively. Thus the analysis run with these components lost explanatory power. The same occurred with the joint model, whose $\mathrm{R}^{2}$ dropped to $54.5 \%$.

In those models generated with one variable per component and the variable Time $(\mathrm{T})$ (models number 4 ), the explanatory power increased slightly to $83.8 \%$ and $79.5 \%$ for Interbrand and Millward Brown, respectively. With Brand Finance, no results appeared in Model 4 because the variables Dividend per share and Time were non-significant. So Model 4 equalled Model 2 for this valuation consultant. The explanatory power of the joint model also slightly rose to $74.0 \%$.

In these models, all variables intervened positively in the three consultancy companies' models to explain brand values, and the three agencies positively valued this information, as the sign of their coefficient denoted. Only the Interbrand ranking was affected by the Time control variable, which is quite natural because it has been the ranking available for most years (2000-2017). The Time variable took a negative sign as it was influenced by the lowest brand value in the first years (2000-2009), as Table 2 shows and Obj. 3 corroborates. The dummy variables of the Interbrand and Brand Finance rankings took a negative sign. This means that if all the other variables were on an equal basis, Interbrand and Brand Finance would value below Millward Brown. This was also seen in the simple models, where the coefficient of Net result was higher for Millward Brown and lower for Brand Finance.

Objective 3. Model the temporal performance of the value of the brands in the IT sector using economic-financial and stock exchange information.

The four models obtained in Table 4 were replicated for shorter equal periods (Attig et al., 2013). This was done only for Interbrand because it has been available for most years (2000-2017). The analysed subperiods contained 9 years each: one went from 2000 to 2008, and the other from 2009 to 2017 . In turn, these two subperiods were divided into two others with a similar duration. Table 5 offers the results of these models. 
Table 5. Linear regression models by periods for the high-value brands of the IT sector estimated by Interbrand

\begin{tabular}{|c|c|c|c|c|c|c|}
\hline & $2000-2008$ & 2009-2017 & $2000-2003$ & 2004-2008 & 2009-2012 & 2013-2017 \\
\hline Constant & $15820.75^{\star \star *}$ & -1256.85 & 3652.60 & 2796.65 & $5147.62^{*}$ & -3893.54 \\
\hline Net Result & $3.98^{* * *}$ & $2.42^{* * *}$ & $4.66^{* * *}$ & $3.16^{* * *}$ & $1.61^{\star \star \star}$ & $2.73^{* * *}$ \\
\hline Listing value & $50.58^{\star}$ & $123.37^{\star * *}$ & $189.18^{\star}$ & & $110.35^{\star \star *}$ & $122.48^{\star * *}$ \\
\hline $\begin{array}{l}\text { Dvd. Per } \\
\text { share }\end{array}$ & $6528.91^{\star *}$ & $5018.44^{\star * *}$ & & $9173.59^{* * *}$ & $7820.58^{\star * *}$ & $3866.73^{\star}$ \\
\hline $\mathrm{T}$ & $-2511.73^{\star * *}$ & & & & & \\
\hline Adjusted $\mathrm{R}^{2}$ & $73.0 \%$ & $87.6 \%$ & $68.9 \%$ & $73.9 \%$ & $77.8 \%$ & $90.7 \%$ \\
\hline $\mathrm{N}$ & 109 & 113 & 45 & 59 & 49 & 64 \\
\hline $\mathrm{CI}$ & 6.049 & 3.212 & 3.035 & 3.683 & 3.420 & 3.395 \\
\hline VIF & 1.276 & 1.071 & 1.065 & 1.243 & 1.023 & 1.063 \\
\hline
\end{tabular}

Note: ${ }^{* *},{ }^{* *}$ and ${ }^{*}$ is the $0.5 \%, 1 \%$ and $5 \%$ level of error, respectively. CI is the condition index which, in all the obtained models, presents a level that is lower than or equals 6.049. VIF is the inflation factor of variance, with a low level in all the models. Thus there was no multicollinearity among variables.

We can see that the models' goodness of fit was higher during the most recent subperiods ( $87.6 \%$ vs. $73.0 \%$ ) when divided into two subperiods, and $90.7 \%$ versus $68.9 \%$ when divided into four subperiods. Three explanatory variables intervened in all the models, namely Net result, Listing value and Dividend per share, except in the model for the 2000-03 period, in which Dividend per share did not intervene, and during the 2004-08 period when Listing value did not intervene. They all took a positive sign. These results confer consistency to those obtained in the previous objective (see Table 4).

The Time variable, which intervened in our previous analysis (see Table 4), had an influence only during subperiod 2000-2008, where the mean brand values were lower (see Table 2).

\section{Objective 4. Model the brand valuations in the IT sector by industries.}

The models obtained by the OLS analyses are shown for four of the industries in the IT sector sample: Consumer electronics (Table 6), Software (Table 7), the Internet, Content \& information (Table 8) and Information technology services (Table 9). The other two industries (Communication equipment and Semiconductors) were removed because they comprised only one company each from the study sample.

The residuals were analysed to check that there was no multicollinearity among the variables in the models. The VIF was below 3.192 and the CI went below 12.049.

In the analyses done by industries, the models' explanatory power improved or they were all quite similar in all cases compared to those devised for the sector as a whole (Models 4 in Table 4), except for the Band Finance ranking in the Information technology services industry, for which the adjusted $\mathrm{R}^{2}$ lowered from $80.2 \%$ to $62.6 \%$.

The only variable that influenced all the rankings in all industries was Net Result. Listing value influenced almost all the models in the Consumer electronics industry and the Internet, 
content \& information industry, but barely had any influence on the other two industries. Dividend per share impacted most of the models from the studied industries, except for the Internet, content \& information industry because none of the companies that it contained had paid out any dividends during the study period.

Finally, the models generated with the joint values of the three rankings confirmed that Interbrand provided lower valuations than Millward Brown, but higher ones than Brand Finance.

Table 6. The linear regression results for the high-value brands of the Consumer electronics industry

\begin{tabular}{|c|c|c|c|c|}
\hline & $\begin{array}{c}\text { Interbrand } \\
(2000-2017)\end{array}$ & $\begin{array}{c}\text { Brand Finance } \\
(2007-2017)\end{array}$ & $\begin{array}{l}\text { Millward Brown } \\
(2006-2017)\end{array}$ & $\begin{array}{c}\text { Three rankings } \\
\text { jointly } 07-17\end{array}$ \\
\hline Constant & -2005.53 & $7413.35^{\star}$ & -10152.12 & $-6855.69^{\star}$ \\
\hline Net Result & $1.30^{\star * *}$ & $1.36^{\star * *}$ & $2.20^{\star * *}$ & $1.54^{\star * *}$ \\
\hline Listing value & $228.97^{\star * *}$ & & $1046.24^{* * *}$ & $415.56^{\star * *}$ \\
\hline Dvd. Per share & $34866.44^{\star * *}$ & $24629.14^{\star * \star}$ & & $24376.06^{* *}$ \\
\hline D. Millward Brown & & & & $12349.00^{* * *}$ \\
\hline Adjusted $\mathrm{R}^{2}$ & $94.7 \%$ & $85.7 \%$ & $78.2 \%$ & $78.5 \%$ \\
\hline $\mathrm{N}$ & 72 & 44 & 48 & 132 \\
\hline $\mathrm{CI}$ & 4.837 & 3.947 & 4.558 & 6.672 \\
\hline VIF & 2.292 & 2.112 & 2.505 & 2.677 \\
\hline
\end{tabular}

Note: ${ }^{* * *},{ }^{* *}$ and ${ }^{*}$ is the $0.5 \%, 0.1 \%$ and $5 \%$ level of error, respectively. CI is the condition index which, in all the obtained models, presents a level that is lower than or equals 6.672. VIF is the inflation factor of variance, with a low level in all the models. Thus there was no multicollinearity among variables.

Table 7. The linear regression results for the high-value brands of the Software industry

\begin{tabular}{|l|c|c|c|c|}
\cline { 2 - 5 } \multicolumn{1}{c|}{} & $\begin{array}{c}\text { Interbrand } \\
(2000-2017)\end{array}$ & $\begin{array}{c}\text { Brand Finance } \\
(2007-2017)\end{array}$ & $\begin{array}{c}\text { Millward Brown } \\
(2006-2017)\end{array}$ & $\begin{array}{c}\text { Three rankings } \\
\text { jointly 07-17 }\end{array}$ \\
\hline Constant & $12428.77^{* * *}$ & $-9270.14^{*}$ & -11040.45 & $-12256.97^{* * *}$ \\
\hline Listing value & $294.40^{* * *}$ & & & \\
\hline Net Result & $3.79^{* * *}$ & $2.47^{* * *}$ & $3.76^{* * *}$ & $3.199^{* * *}$ \\
\hline Dvd. Per share & & $13438.70^{* * *}$ & $26465.54^{* * *}$ & $17098.23^{* * *}$ \\
\hline T & $-2115.37^{* * *}$ & & & \\
\hline D. Brand Finance & & & & $-7625.43^{*}$ \\
\hline D. Millward Brown & & & & $13716.66^{* * *}$ \\
\hline Adjusted R $\mathrm{R}^{2}$ & $81.7 \%$ & $79.0 \%$ & $75.0 \%$ & $75.4 \%$ \\
\hline $\mathrm{N}$ & 54 & 33 & 36 & 99 \\
\hline CI & 8.033 & 4.744 & 4.425 & 5.899 \\
\hline VIF & 1.301 & 1.051 & 1.026 & 1.017 \\
\hline
\end{tabular}

Note: ${ }^{* * *}$ and ${ }^{*}$ is the $0.5 \%$ and $5 \%$ level of error, respectively. CI is the condition index which, in all the obtained models, presents a level that is lower than or equals 8.033. VIF is the inflation factor of variance, with a low level in all the models. Thus there was no multicollinearity among variables. 
Table 8. The linear regression results for the high-value brands of the Internet, content \& information industry

\begin{tabular}{|l|c|c|c|c|}
\cline { 2 - 5 } \multicolumn{1}{c|}{} & $\begin{array}{c}\text { Interbrand } \\
(2000-2017)\end{array}$ & $\begin{array}{c}\text { Brand Finance } \\
(2007-2017)\end{array}$ & $\begin{array}{c}\text { Millward Brown } \\
(2006-2017)\end{array}$ & $\begin{array}{c}\text { Three rankings } \\
\text { jointly 07-17 }\end{array}$ \\
\hline Constant & $-26207.46^{\star * *}$ & 5495.52 & $19595.10^{*}$ & -9173.23 \\
\hline Listing value & $126.70^{\star * *}$ & $71.28^{\star * *}$ & $149.37^{\star * *}$ & $117.00^{\star * *}$ \\
\hline Net Result & $2.12^{\star * *}$ & $1.90^{\star}$ & $4.81^{\star * *}$ & $3.24^{\star * \star}$ \\
\hline T & $1725.94^{\star}$ & & & \\
\hline D. Brand Finance & & & & $-15091.20^{\star}$ \\
\hline D. Millward Brown & & & & $54733.88^{\star * *}$ \\
\hline Adjusted R & & $89.3 \%$ & $91.7 \%$ & $89.6 \%$ \\
\hline N & $97.1 \%$ & 22 & 24 & 66 \\
\hline CI & 36 & 6.287 & 5.651 & 6.646 \\
\hline VIF & 12.049 & 1.817 & 2.178 & 2.082 \\
\hline
\end{tabular}

Note: ${ }^{* *}$ and ${ }^{*}$ is the $0.5 \%$ and $5 \%$ level of error, respectively. CI is the condition index which, in all the obtained models, presents a level that is lower than or equals 12.049. VIF is the inflation factor of variance, with a low level in all the models. Thus there was no multicollinearity among variables.

Table 9. The linear regression results for the high-value brands of the Information technology services industry

\begin{tabular}{|l|c|c|c|c|}
\cline { 2 - 5 } \multicolumn{1}{c|}{} & \begin{tabular}{c} 
Interbrand \\
\multicolumn{1}{c|}{$(2000-2017)$}
\end{tabular} & $\begin{array}{c}\text { Brand Finance } \\
(2007-2017)\end{array}$ & $\begin{array}{c}\text { Millward Brown } \\
(2006-2017)\end{array}$ & $\begin{array}{c}\text { Three rankings } \\
\text { jointly } 07-17\end{array}$ \\
\hline Constant & 4635.14 & $13084.67^{* *}$ & -6309.48 & $-14891.72^{* * *}$ \\
\hline Listing value & & & & $258.66^{* * *}$ \\
\hline Net Result & $5.49^{* * *}$ & $1.64^{* * *}$ & $4.66^{* * *}$ & $3.45^{* * *}$ \\
\hline Dvd. Per share & $-3929.31^{\star}$ & & $8723.11^{* * *}$ & \\
\hline D. Brand Finance & & & & $-23733.26^{* * *}$ \\
\hline D. Millward Brown & & & & $15825.59^{* * *}$ \\
\hline Adjusted $R^{2}$ & $89.7 \%$ & $62.6 \%$ & $92.2 \%$ & $82.3 \%$ \\
\hline N & 36 & 22 & 24 & 66 \\
\hline CI & 4.722 & 4.866 & 5.358 & 8.155 \\
\hline VIF & 2.060 & 1.000 & 2.045 & 1.915 \\
\hline
\end{tabular}

Note: ${ }^{* *},{ }^{* *}$ and ${ }^{*}$ is the $0.5 \%, 1 \%$ and $5 \%$ level of error, respectively. CI is the condition index which, in all the obtained models, presents a level that is lower than or equals 8.155. VIF is the inflation factor of variance, with a low level in all the models. Thus there was no multicollinearity among variables.

\section{Discussion}

This work firstly analysed the international valuation brand rankings in the IT sector for the period 2000-2017. Some authors (Munteanu \& Florea, 2012; Salinas \& Ambler, 2009) have theoretically demonstrated that depending on the valuation methodology followed, the brand value results can differ. Nonetheless, no previous study has evidenced this empirically with the valuations made by prestigious international consultancy companies. Some 
research works have employed one of the three rankings (Basgoze et al., 2016; Flisikowski \& Kucharska, 2018; Johansson et al., 2012; Kucharska et al., 2018; Ratnatunga \& Ewing, 2009) for different purposes, but it is impossible to compare them. There are three exceptions (Alcaide et al., 2019; Bagna et al., 2017; Janoskova \& Krizanova, 2017). This last study cannot be compared either because it analysed the relation between brand value and CSR. However, Bagna et al. (2017) covered a 3-year period and concluded that Brand Finance used the most prudent brand evaluation method. Our results match this research, and explains brand value based on economic variables (revenue, sales, sales growth) with $\mathrm{R}^{2}$ values between $58 \%$ and $73 \%$. The same year Janoskova and Krizanova (2017) studied the correlation between four rankings, covering a 4-year period without modelling. In line with their results, our models show how Millward Brown scores larger brand values than the other two analysed consultancy companies. Thus, our study corroborates empirically the existence of significant differences in the brand valuations reported by the three most internationally recognised consultancy companies. This derives from not only the intangible characteristic of brands, but also from there being no active market for selling brands that would allow us to compare market values to the values assigned by the consultants to brands, which occurs with other assets like real estate, for which many studies can be found and have developed sophisticated models (Abidoye et al., 2019; Adebayo et al., 2019; Guadalajara \& López, 2018; Lisi, 2019). It is desirable to conduct quantitative works on brand value that contribute to improve our knowledge of the most appropriate methodologies for these assets.

Secondly, this research modelled brand values that had been published by the three international consultancy companies using economic-financial and stock exchange variables over an 18-year period. The possibility of explaining the brand values made by international consultancy companies using only economic-financial and stock exchange information was demonstrated to a great extent. Specifically, the present research demonstrated that the net results of a company owing a brand could explain between around $47 \%$ and $65 \%$ of the brand values that consultancy companies score. When we added the share listing, which corresponds to brand strength or the capacity to make future income up to a point, the brand value's explanatory power increased by between $20-30 \%$, and slightly rose by approx. $2 \%$ when we added the variable Dividend per share to the models. As expected, the models' explanatory power lowered to between $48.8-68.8 \%$ when the PCA were used (Models 3 ). Thus the Millward Brown brand values are mainly explained by the brand strength and consumer behaviour or to share listing (30\%), while the model grants less relevance to the company's net result (46.7\%) in comparison with the Brand Finance and the Interbrand ones (about $65 \%$ for the net result and $15 \%$ for the listing value).

Therefore, the present work generates quantitative valuation models for brands from the IT sector, with a confidence level between $73 \%$ and $80 \%$. It can be used by industrial practitioners, valuation professionals and companies themselves to value other brands in the same sector that are not considered in brand rankings. It involves using the market approach instead of the income-based approach, where one of the most controversial aspects is capitalisation rate. In these models that employ a market approach, this parameter is obvious and only the economic data extracted from the accounting of companies and the Stock market are used. In addition, the corrective parameter (brand strength) of the revenue update, which 
the consultants use for valuing brands, and for which no clear calculation procedure exists, also disappears in our models. Furthermore, these models have the quality of being objective, reliable and transparent, and they also facilitate calculating and acquiring the required data, unlike the models used by the three consultants herein employed. This is especially interesting for those companies that own recognised and older brands, which may use simpler valuation methodologies that employ only the financial and stock exchange results generated by the companies themselves. This implies that these models will be more reliable, objective and verifiable (IFRS Standards, 2018), which are three characteristics sought by companies to implement such models into their accountancy. Our results also prove relevant for shareholders, investors and other financial agents because it is not always easy to measure this intangible asset in an isolated fashion, nor are brand values reliable.

Other authors have developed theoretical brand valuation models from only the economic-financial perspective (Aaker, 1991; Hirose, 2002), but have not used the rankings of international consultancy companies. So it is impossible to compare our results to know which models better explain these values.

Thirdly, we verified that the obtained quantitative models are dynamic in time as some differences among variables were observed between the most recent subperiods of 2000-2008 and 2000-2003, and the most up-to-date ones. Listing value did not intervene during the 2000-03 period, and Dividend per share did not intervene in 2004-08. This means that the methodology used by Interbrand is updated with time and may pay more attention to the results that affect financial markets, e.g. brand strength, while more attention was paid some years ago to a company's economic results, such as net result.

The models' goodness of fit during the more recent subperiods was very high, between $87.6 \%$ and $90.7 \%$. This denotes that Interbrand's more recent brand values can be explained by economic-financial and stock exchange variables to a greater extent, which makes the results of this contribution more reliable.

Fourthly, the analysis by industries indicated that, in all cases but one (the Brand Finance model in the Information technology services industry), the statistics of the models (adjusted $\mathrm{R}^{2}$, $\mathrm{t}$ de Student, CI and VIF) improved or continued to be quite similar to those of the IT sector as a whole; that is, the explanatory power of the economic-financial and stock exchange variables was more relevant in these models. This indicates the suitability of using specific models for industries with more homogeneous characteristics than the models obtained for all the business in the sector. Moreover, the variable Net result explained the brand value in all the rankings of all industries, which was not the case with the other variables (Listing value and Dividend per share). All this confers robustness to the results corresponding to Objective 2 and also confirms them. This ratifies that the companies' Net Results are able to explain most of a brand's value, which can often increase by using other objective variables (Listing value and Dividend per share).

The present study modelled the brand values taken as market values in a possible sale. One study limitation could possibly be its sample size. Another limitation could be that models were obtained for mature listed companies that are well-established internationally, these results may not be applicable to start-ups or growing companies. So it would be interesting to model the brand value of emerging IT companies in future work to identify and quantify 
the drivers that explain the brand creation concept and to compare them with mature companies in the sector.

Research also could continue by developing models to estimate the brand value of multibrand companies to understand companies' synergies and differences in their values. Such studies could be extrapolated to other sectors to model their characteristics and differences.

\section{Conclusions}

The brand values employed by the valuing consultants may act as a reference as there is no transparent brands market with which to use a market approach in brand valuing in accordance with Standards IAS, IVS and RICS. Nevertheless, it can be concluded from the obtained results that the brand values in each valuing consultant differ, which makes their applicability doubtful. This study demonstrates how the three valuing consultants agree that the Net result explains, to a greater extent, brand values as opposed to other aspects like firm size or being present in other countries, which is coherent with the methodology that they apply. In this way, it is possible to employ simple objective methods with the obtained models to value brands rather than the scarcely transparent sophisticated methods that consultancy firms employ.

Using these models will allow investors to obtain benefits to define their investment strategies, professional brand valuers as they will gain quick objective criteria for valuing, as well as the main management teams of companies owing brands because they will easily know the evolution of their brand value.

\section{Author contributions}

Three authors (MA, NG and EDLP) conceived the study and were responsible for its design. MA was responsible for data collection and analysis. MA, NG and EDLP were responsible for data interpretation. MA wrote the first draft of the article, which was enhanced with contributions from NG and EDLP.

\section{Disclosure statement}

Authors declare not having any competing financial, professional, or personal interests from other parties.

\section{References}

Aaker, D. A. (1991). Managing brand equity. Capitalizing on the value of a brand name. The Free Press. Aaker, D. A. (1996). Building strong brands. The Free Press.

Abidoye, R. B., Junge, M., Lam, T., Oyedokun, T. B., \& Tipping, M. L. (2019). Property valuation methods in practice: Evidence from Australia. Property Management, 37(5), 701-718. https://doi.org/10.1108/PM-04-2019-0018

Abratt, R., \& Bick, G. (2003). Valuing brands and brand equity: Pitfalls and processes. Journal of Applied Management and Entrepreneurship, 8, 21-39. 
Adebayo, A. A., Greenhalgh, P., \& Muldoon-Smith, K. (2019). Investigating retail property market dynamics though spatial accessibility measures. Journal of European Real Estate Research, 12(2), 155-172. https://doi.org/10.1108/JERER-01-2018-0009

Agus, M., \& Salas, T. (2017). Strategic and institutional sustainability: Corporate social responsibility, brand value, and Interbrand listing. Journal of Product \& Brand Management, 26(6), 545-558. https://doi.org/10.1108/JPBM-07-2016-1277

Alcaide, M. A., De la Poza, E., \& Guadalajara, M. N. (2019). Assessing the sustainability of high-value brands in the IT sector. Sustainability, 11(6), 1598. https://doi.org/10.3390/su11061598

Alcaide, M. A., De la Poza, E., \& Guadalajara, M. N. (2020). The impact of corporate social responsability transparency on the financial performance, brand value, and sustainability level of IT companies. Corporate Social Responsibility and Environmental Management, 27(2), 642-654. https://doi.org/10.1002/csr.1829

Améstica, L., \& King, A. (2017). Importancia y valor económico de la marca en el sistema universitario. Opción: Revista de Ciencias Humanas y Sociales, 33(83), 545-571.

Asfuroglu, D., Ökten, N. Z., \& Okan, E. Y. (2020). Examining economic growth through brand development: A multinational analysis. Sage Open, 10(2), 1-9. https://doi.org/10.1177/2158244020921871

Asikainen, A. L., \& Mangiarotti, G. (2016). Open innovation and growth in IT sector. Service Business, 11, 45-68. https://doi.org/10.1007/s11628-015-0301-2

Attig, N., El Ghoul, S., Guedhami, O., \& Suh, J. (2013). Corporate social responsibility and credit ratings. Journal of Business Ethics, 10(6), 15-28. https://doi.org/10.1007/s10551-013-1714-2

Bagna, E., Dicuonzo, G., Perrone, A., \& Dell'Atti, V. (2017). The value relevance of brand valuation. Applied Economics, 49(58), 5865-5876. https://doi.org/10.1080/00036846.2017.1352078

Bank, S., Yazar, E. R., \& Sivri, U. (2020). The portfolios with strong brand value: More returns? Lower risk? Borsa Istanbul Review, 20(1), 64-79. https://doi.org/10.1016/j.bir.2019.09.001

Basgoze, P., Yildiz, Y., \& Camgoz, S. M. (2016). Effect of brand value announcements on stock returns: Empirical evidence from Turkey. Journal of Business Economics and Management, 17(6), 1252-1269. https://doi.org/10.1080/00036846.2017.1352078

Bistrova, J., Lace, N., Tamosiuniene, R., \& Kozlovskis, K. (2017). Does firm’s higher innovation potential lead to its superior financial performance? Case of CEE countries. Technological and Economic Development of Economy, 23(2), 375-391. https://doi.org/10.3846/20294913.2016.1266411

Brand Finance. (2019). Brand valuation methodology. https://brandirectory.com/methodology

Casado, A. B., Pérez, L. M., \& Sellers, R. (2017). Aggregate consumer ratings and booking intention: The role of brand image. Service Business, 11, 543-562. https://doi.org/10.1007/s11628-016-0319-0

Chao, W., Li, H., \& Shyh, F. (2009). Constructing a relationship-based brand equity model. Service Business, 3, 275-292. https://doi.org/10.1007/s11628-008-0062-2

Cheng, A.-C. (2013). A fuzzy multiple criteria comparison of technology valuation methods for the new materials development. Technological and Economic Development of Economy, 19(3), 397-408. https://doi.org/10.3846/20294913.2013.821687

Cid-López, A., Hornos, M. J., Carrasco, R. A., \& Herrera-Viedma, E. (2015). A hybrid model for decision-making in the information and communications technology sector. Technological and Economic Development of Economy, 21(5), 720-737. https://doi.org/10.3846/20294913.2015.1056281

Damodaran, A. (1994). Damodaran on valuation. John Wiley and Sons.

Damodaran, A. (2012). Investment valuation: Tools and techniques for determining the value of any asset. John Wiley and Sons.

De Oliveira, M. O. R., Stefanan, A. A., \& Lobler, M. L. (2018). Brand equity, risk and return in Latin America. Journal of Product and Brand Management, 27(5), 557-572.

https://doi.org/10.1108/JPBM-02-2017-1418 
Dorfleitner, G., Röble, F., \& Lesser, K. (2019). The financial performance of the most valuable brands: A global empirical investigation. Heliyon, 5(4), e01433. https://doi.org/10.1016/j.heliyon.2019.e01433

Dutordoir, M., Verbeeten, F., \& De Beijer, D. (2015). Stock price reactions to brand value announcements: Magnitude and moderators. International Journal of Research in Marketing, 32(1), 34-47. https://doi.org/10.1016/j.ijresmar.2014.08.001

Eng, L., \& Keh, H. (2007). The effects of advertising and brand value on future operating and market performance. Journal of Advertising, 36(49), 91-100. https://doi.org/10.2753/JOA0091-3367360407

Erdem, T., \& Swait, J. (1998). Brand equity as a signaling phenomenon. Journal of Consumer Psychology, 7(2), 131-157. https://doi.org/10.1207/s15327663jcp0702_02

Flisikowski, K., \& Kucharska, W. (2018). The condition of economies. Do most valuable global brands matter? Equilibrium. Quarterly Journal of Economics and Economic Policy, 13(2), 251-264. https://doi.org/10.24136/eq.2018.013

González, O., Berenguer, G., \& Serra, A. (2019). The impact of value co-creation on hotel brand equity and customer satisfaction. Tourism Management, 75, 51-65. https://doi.org/10.1016/j.tourman.2019.04.024

Guadalajara, N., \& López, M. A. (2018). The inflated valuation problem in Valencia, Spain, and implications for firm size. International Journal of Strategic Property Management, 22(4), 300-313. https://doi.org/10.3846/ijspm.2018.4348

Gujarati, D. N. (2003). Basic econometrics (4 ${ }^{\text {th }}$ ed.). McGraw-Hill.

Haigh, D. (1996). Founder and CEO, brand finance. http://brandfinance.com/who-we-are/our-people/ person/david-haigh/

He, Q., Guaita-Martínez, J. M., \& Botella-Carrubi, D. (2020). How Brand equity affects firm productivity: The role of R\&D and human capital. Economic Research-Ekonomska Istraživanja, 33(1), 29762992. https://doi.org/10.1080/1331677X.2019.1686045

Hirose, Y. (2002). The report of the committee on brand valuation. Ministry of Economy, Trade and Industry (METI). The Government of Japan.

Hoeffler, S., \& Keller, K. (2003). The marketing advantage of strong brands. Journal of Brand Management, 10(6), 421-445. https://doi.org/10.1057/palgrave.bm.2540139

Honamardi, Z., Sepasi, S., \& Azar, A. (2019). Comparing the impact of brand value on corporate profit in B2B and B2C businesses: A case study. Iranian Journal of Management Studies, 12(1), 121-147. https://doi.org/10.22059/IJMS.2018.261053.673187

Interbrand. (2019). Methodology. https://www.interbrand.com/best-brands/best-global-brands/methodology/

International Financial Reporting Standards (IFRS Standards). (2018). Issued IFRS Standards 2018 (Red Book). https://www.ifrs.org/news-and-events/2018/03/issued-ifrs-standards-2018-red-bookavailable-to-order-now/

International Organization for Standardization. (2010). Brand valuation - Requirements for monetary brand valuation (ISO 10668). https://www.iso.org/standard/46032.html

International Valuation Standards Council. (2017). International Valuation Standards. https://www.ivsc. org/standards/international-valuation-standards

Janoskova, K., \& Krizanova, A. (2017). Comparison of selected internationally recognized brand valuation methods. Oeconomia Copernicana, 8(1), 99-110. https://doi.org/10.24136/oc.v8i1.7

Johansson, J. K., Dimofte, C. V., \& Mazvancheryl, S. K. (2012). The performance of global brands in the 2008 financial crisis: A test of two brand value measure. International Journal of Research in Marketing, 29(3), 235-245. https://doi.org/10.1016/j.ijresmar.2012.01.002

Juliá-Igual, J. F., Cervelló-Royo, R., \& Berné-Lafuente, I. (2017). Market value analyses of a Chinese e-commerce holding group: A multicriteria approach. Service Business, 11(3), 475-490.

https://doi.org/10.1007/s11628-016-0316-3 
Kamakura, W. A., \& Russell, G. J. (1993). Measuring brand value with scanner data. International Journal of Research in Marketing, 10(1), 9-22. https://doi.org/10.1016/0167-8116(93)90030-3

Kantar. (2019). Millward Brown. http://www.millwardbrown.com/brandz/rankings-and-reports/topglobal-brands/2015/methodology

Kapferer, J. N., \& Thoenig, J. C. (1991). The Brand: Engine of competitiveness of the companies and growth of the economies. McGraw-Hill Editions.

Keller, K. L. (1993). Conceptualizing, measuring and managing customer-based brand equity. Journal of Marketing, 57(1), 1-22. https://doi.org/10.1177/002224299305700101

Keller, K. L., \& Lehmann, D. R. (2006). Brands and branding: Research findings and future priorities. Marketing Science, 25(6), 740-759. https://doi.org/10.1287/mksc.1050.0153

Kim, E. (2019). A study on the Chinese translation methods of multinational brand name. The Journal of Humanities and Social Science, 10(2), 129-140. https://doi.org/10.22143/HSS21.10.2.10

Kotler, P., \& Keller, K. L. (2006). Marketing management. Prentice-Hall International Edition.

Kucharska, W., Flisikowski, K., \& Confente, I. (2018). Do global brands contribute to the economy of their country of origin? A dynamic spatial approach. Journal of Product \& Brand Management, 27(7), 768-780. https://doi.org/10.1108/JPBM-10-2017-1641

Lambin, J. (1995). Strategic marketing. McGraw-Hill Editions.

Lee, Y., \& Kim, I. (2019). A value co-creation model in brand tribes: The effect of luxury cruise consumers' power perception. Service Business, 13, 129-152. https://doi.org/10.1007/s11628-018-0373-X

Li, Y., Lee, S. G., \& Kong, M. (2019). The industrial impact and competitive advantage of China's ICT industry. Service Business, 13, 101-127. https://doi.org/10.1007/s11628-018-0368-7

Lisi, G. (2019). Property valuation: The hedonic pricing model-location and housing submarkets. Journal of Property Investment \& Finance, 37(6), 589-596. https://doi.org/10.1108/JPIF-07-2019-0093

Majerova, J., \& Kliestik, T. (2015). Brand valuation as immanent component of brand value building and managing. Procedia Economics and Finance, 26, 546-552.

https://doi.org/10.1016/S2212-5671(15)00953-3

Martín Benito, J. (2011). El nuevo estándar ISO de valoración de marcas. MK Marketing+Ventas, 267. http://pdfs.wke.es/4/5/8/2/pd0000064582.pdf

Matsumura, H., Ueda, T., \& Sagane, Y. (2019). Data on the correlations among brand value, market capitalization, and consolidates overseas sales ratios of Japanese companies. Data in Brief, 23, 103808. https://doi.org/10.1016/j.dib.2019.103808

Munteanu, C. C., \& Florea, D. (2012). A critical analysis of brand equity evaluation methods. Revista economică, 3(Supl), 254-260.

Ökten, N. Z., Okan, E. Y., Arslan, Ü., \& Güngör, M. O. (2019). The effect of brand value on economic growth: A multinational analysis. European Research on Management and Business Economics, 25(1), 1-7. https://doi.org/10.1016/j.iedeen.2018.11.002

Pahud de Mortanges, C., \& Van Riel, A. (2003). Brand equity and shareholder value. European Management Journal, 21(4), 521-527. https://doi.org/10.1016/S0263-2373(03)00076-8

Ratnatunga, J., \& Ewing, M. T. (2009). An ex-ante approach to brand capability valuation. Journal of Business Research, 62(3), 323-331. https://doi.org/10.1016/j.jbusres.2008.04.003

Ray, K., \& Sharma, M. (2020). Antecedents and outcomes of brand strength: A study of Asian IT organizations towards brand sustainability. Corporate Reputation Review. https://doi.org/10.1057/s41299-020-00097-y

Rodríguez, A., Caballer, V., \& Guadalajara, N. (2011). Assessing the intangibles transferred in franchise businesses. Service Business, 5(1), 29-46. https://doi.org/10.1007/s11628-011-0100-3 
Royal Institution of Chartered Surveyors. (2020). RICS valuation - global standards. https://www.rics. org/globalassets/rics-website/media/upholding-professional-standards/sector-standards/valuation/ rics-valuation--global-standards-jan.pdf

Salinas, G. (2009). The international brand valuation manual. John Wiley \& Sons Ltd.

Salinas, G., \& Ambler, T. (2009). A taxonomy of brand valuation practice: Methodologies and purposes. Journal of Brand Management, 17, 39-61. https://doi.org/10.1057/bm.2009.14

Seetharaman, A., Azlan, Z., \& Gunalan, S. (2001). A conceptual study on brand valuation. Journal of Product \& Brand Management, 10(4), 243-256. https://doi.org/10.1108/EUM0000000005674

Simon, J., \& Sullivan, M. (1993). The measurement and determinants of brad equity: A financial approach. Journal of Marketing Science, 12(1), 1-124. https://doi.org/10.1287/mksc.12.1.28

Srinivasan, V., Park, C., \& Chang, D. (2001). Equitymap: Measurement, analysis, and prediction of brand equity and its sources. Research Paper Series, 1685, 110.

Virvilaité, R., \& Jucaitytè, I. (2008). Brand valuation: Viewpoint of costumer and company. Engineering Economics, 56, 111-119.

Wang, D. H. M., Yu, T. H. K., \& Ye, F. R. (2012). The value relevance of brand equity in the financial services industry: An empirical analysis using quantile regression. Service Business, 6(4), 459-471. https://doi.org/10.1007/s11628-012-0156-8

Yang, T.-Y., Yang, Y.-T., Chen, J.-R., \& Lu, C.-C. (2019). Correlation between owner brand and firm value - Case study on a private brand in Taiwan. Asia Pacific Management Review, 24(3), 232-237. https://doi.org/10.1016/j.apmrv.2018.06.002

Yeh, L.-T., \& Chang, D.-S. (2020). Using categorical dea to assess the effect of subsidy policies and technological learning on R\&D efficiency of IT industry. Technological and Economic Development of Economy, 26(2), 311-330. https://doi.org/10.3846/tede.2019.11411

Zahari, A. R., Esa, E., Rajadurai, J., Azizan, N. A., \& Muhamad Tamyez, P. F. (2020). The effect of corporate social responsibility practices on Brand equity: An examination of Malaysia's top 100 brands. Journal of Asian Finance, Economics and Business, 7(2), 271-280.

https://doi.org/10.13106/jafeb.2020.vol7.no2.271 


\section{APPENDIX}

Matrix resulting from the PCA

\begin{tabular}{|c|c|c|c|c|c|c|}
\hline \multicolumn{7}{|c|}{ Rotated components matrix ${ }^{\mathrm{a}}$} \\
\hline & \multicolumn{3}{|c|}{ Gross } & \multicolumn{3}{|c|}{ Rescaled } \\
\hline & \multicolumn{3}{|c|}{ Component } & \multicolumn{3}{|c|}{ Component } \\
\hline & 1 & 2 & 3 & 1 & 2 & 3 \\
\hline Current Asset & 23081772.228 & 9227752.083 & 10092596.483 & 0.809 & 0.324 & 0.354 \\
\hline Capital & 15282084.542 & 1142392.328 & -1799567.390 & 0.786 & 0.059 & -0.093 \\
\hline $\mathrm{R}+\mathrm{D}$ & 2467220.670 & 381268.339 & 1160034.775 & 0.764 & 0.118 & 0.359 \\
\hline Total Assets & 40574998.763 & 37674406.105 & 20617278.137 & 0.678 & 0.629 & 0.344 \\
\hline Dividends & 1489880.483 & 949640.785 & 486919.410 & 0.563 & 0.359 & 0.184 \\
\hline Year & 2.655 & 0.917 & 0.270 & 0.535 & 0.185 & 0.054 \\
\hline Listing value & 47.545 & -25.677 & 31.885 & 0.405 & -0.219 & 0.272 \\
\hline $\begin{array}{l}\text { Number of } \\
\text { shares }\end{array}$ & 19531177.695 & 661728.854 & 22842402.803 & 0.640 & 0.022 & 0.748 \\
\hline $\begin{array}{l}\text { Accounting / } \\
\text { listing value }\end{array}$ & -0.317 & -0.066 & -0.022 & -0.186 & -0.039 & -0.013 \\
\hline Payout & 0.029 & -0.005 & -0.005 & 0.097 & -0.018 & -0.017 \\
\hline $\begin{array}{l}\text { Total } \\
\text { liabilities }\end{array}$ & 19253379.747 & 35827776.170 & 2689987.025 & 0.468 & 0.871 & 0.065 \\
\hline $\begin{array}{l}\text { Current } \\
\text { liabilities }\end{array}$ & 6526256.317 & 15420115.845 & 5128449.521 & 0.364 & 0.861 & 0.286 \\
\hline Debt & -0.012 & 0.163 & -0.067 & -0.056 & 0.775 & -0.317 \\
\hline Sales & 10775444.477 & 31460426.308 & 28013014.657 & 0.245 & 0.716 & 0.638 \\
\hline $\begin{array}{l}\text { Number of } \\
\text { employees }\end{array}$ & -11304.045 & 70034.101 & 2609.522 & -0.101 & 0.623 & 0.023 \\
\hline $\begin{array}{l}\text { Accounts } \\
\text { receivable }\end{array}$ & 2574889.738 & 3707867.036 & 3706704.225 & 0.414 & 0.597 & 0.597 \\
\hline Liquidity & 0.494 & -1.181 & -0.069 & 0.208 & -0.496 & -0.029 \\
\hline $\begin{array}{l}\text { Dividend per } \\
\text { share }\end{array}$ & 0.133 & 0.387 & -0.105 & 0.151 & 0.439 & -0.119 \\
\hline $\begin{array}{l}\text { Profitability } \\
\text { from } \\
\text { dividends }\end{array}$ & 0.000 & 0.005 & 0.001 & -0.026 & 0.308 & 0.053 \\
\hline Tax rate & 0.004 & 0.117 & -0.102 & 0.008 & 0.273 & -0.239 \\
\hline ROE & 0.010 & 0.027 & -0.015 & 0.046 & 0.127 & -0.072 \\
\hline PER & -1.762 & -9.423 & -2.517 & -0.022 & -0.120 & -0.032 \\
\hline Leverage & 0.804 & 0.840 & 0.264 & 0.084 & 0.088 & 0.028 \\
\hline Margin & 25.475 & 27.635 & 23.027 & 0.055 & 0.060 & 0.050 \\
\hline $\begin{array}{l}\text { Operating } \\
\text { income }\end{array}$ & 5556809.050 & 2951575.460 & 6498846.180 & 0.489 & 0.260 & 0.572 \\
\hline
\end{tabular}


End of Appendix

\begin{tabular}{|l|c|c|c|c|c|c|}
\hline \multirow{2}{*}{} & \multicolumn{5}{|c|}{ Rotated components matrix ${ }^{\mathrm{a}}$} & \multicolumn{3}{c|}{ Rescaled } \\
\cline { 2 - 7 } & \multicolumn{3}{|c|}{ Gross } & \multicolumn{3}{c|}{ Component } \\
\cline { 2 - 7 } & 1 & 2 & 3 & 1 & 2 & 3 \\
\hline Net income & 4365544.631 & 2358766.228 & 4995814.505 & 0.494 & 0.267 & 0.565 \\
\hline $\begin{array}{l}\text { Sales per } \\
\text { employee }\end{array}$ & 133.515 & -37.593 & 232.221 & 0.256 & -0.072 & 0.445 \\
\hline $\begin{array}{l}\text { Financial } \\
\text { expenses }\end{array}$ & 95491.361 & 207065.434 & 463557.661 & 0.083 & 0.181 & 0.405 \\
\hline $\begin{array}{l}\text { Accounting } \\
\text { value }\end{array}$ & 12.931 & -10.516 & 15.737 & 0.306 & -0.249 & 0.372 \\
\hline EPS & 1.895 & -0.707 & 2.446 & 0.266 & -0.099 & 0.343 \\
\hline Book value & 0.216 & -0.112 & -0.786 & 0.064 & -0.033 & -0.233 \\
\hline ROA & -0.029 & -0.037 & 0.052 & -0.102 & -0.128 & 0.183 \\
\hline
\end{tabular}

Notes: Extraction method: PCA; Rotation method: Varimax Normalization with Kaiser; ${ }^{\text {a Rotation was }}$ converged in five iterations. 